\title{
The 2005 Riots in France: The International Impact of Domestic Violence
}

\section{Harlan Koff and Dominique Duprez}

Following the Autumn 2005 riots in France, many observers in both the popular and the academic press argued that the urban violence that occurred over a two-week period was an open challenge to the French Republican model of citizenship, which does not recognise racial, ethnic or religious affiliations. Many experts focused their analyses of the riots on the relationship between discrimination and ethnic mobilisation in disadvantaged neighbourhoods. Often, the discussions surrounding the uprisings were embedded in the ongoing debate between liberal and communitarian notions of citizenship and the lack of ethnic recognition in France. The articles in this special issue of JEMS indicate another interpretation of the events of October-November 2005. According to much of the comparative analysis presented in this collection, the riots were not a challenge to the French Republic but a demonstration of its schizophrenic characteristics.

Keywords: France; Exclusion; Leadership; Democracy; Republicanism

\section{Introduction}

Zied Benna, a 15-year-old of Tunisian origin, and Bouna Traoré, a 17-year-old of Malian background, both the sons of dustmen in Paris, were killed accidentally on 27 October 2005. Believing themselves to have been followed by the police on their return from a football match, they hid in an EDF (French electricity company) transformer and were electrocuted. Their deaths provoked riots in Clichy-sous-Bois where the tragedy occurred. This violence spread quickly throughout many poor suburbs of Paris. Over the following three weeks it spread to neighbourhoods

\footnotetext{
Harlan Koff is Associate Professor of Political Science at the University of Luxembourg. Correspondence to: Dr H. Koff, Laboratoire de Sciences Politiques, University of Luxembourg, Campus Walferdange, Route de Diekirch, BP2, L-7220 Walferdange, Luxembourg. E-mail: harlan.koff@uni.lu. Dominique Duprez is Research Director at CNRS/Clersé, University of Lille. Correspondence to: Prof. D. Duprez, Clersé-UMRCNRS 8019, Université des Sciences et Technologies de Lille, 59655 Villeneuve d’Ascq Cédex, France. E-mail: Dominique.duprez@univlille1.fr
} 
classified as ZUS - Zones Urbaines Sensibles or 'sensitive urban zones' - in the 200 main cities of France.

Thus, in October 2005, France began to burn. Throughout the world, television stations and newspapers showed sensational images of French cities in flames'. Immediately, French officials began spreading their message that the violence was being exaggerated. Ex-Prime Minister Dominique de Villepin even refuted the use of the term 'riot' in an interview with $\mathrm{CNN}$, suggesting that the events that his country was experiencing were merely a form of 'disorder'. While debates arose concerning the proper label for the uprising, there was common recognition that the damage to French cities was significant. The damage included the burning of 10,000 private vehicles, 30,000 rubbish bins, hundreds of public buildings, buses and post-office vehicles (see Mucchielli in this special issue). The total cost of the urban violence amounted to over 200 million euros. Despite the fact that there were no deaths directly caused by the uprisings, the material damage was so great that many observers called this violence the most significant protest in France since the events of May 1968.

These views were openly discussed by academics, politicians and representatives of non-governmental organisations during a conference on the riots - from which the papers in this special issue derive-sponsored by the Centre Lillois d'Etudes Sociologiques et Économiques (Clersé), at the University of Lille 1, in January 2006. The articles contend that debates on the riots cannot be limited to studies of the position of ethnic minorities in France. Instead, the 2005 violence has highlighted the need to discuss the state of republican democracy in France. French policies towards migrants and minorities highlight many of the structural questions that have led to numerous instances of conflict over the last three years, including the 2006 students' strikes, the 2007 riots in Parisian suburbs (see below), and national mass transit strikes which took place in the same year. Thus, social conflict indicates endemic problems associated with the quality of French democracy.

In fact, during the January conference, Jean-Pierre Balduyck, mayor of the northern French city of Tourcoing, stated: 'I fear for democracy in France'. Mayor Balduyck based his bold statement more on the public and governmental responses to the Autumn 2005 uprisings than on the actual riots themselves. The legacy of the riots may be less related to the actual rebellion by youth in poor urban neighburhoods and more closely connected with French political responses - or the lack thereof - to the urban disorder.

Scholars of French politics have often observed that the more things change, the more they stay the same (plus ça change, plus c'est la même chose). The 1968 student uprisings somehow challenged this notion. These protests led to the downfall of President de Gaulle, challenged his form of authoritarian leadership, and opened access to traditional political channels (Macridis 1975). These movements were so significant in French politics that they were still remembered and cited in 2005 when the Autumn riots occurred. Conversely, the violent urban disorder that touched virtually every French city in 2005 quickly dissipated from France's collective memory 
just weeks after it was suppressed by French police. In May 2007, Nicolas Sarkozy, the man whose words instigated the spread of the urban violence, was elected President of France, in part due to promises to guarantee urban security and halt immigration. Thus, the impact of the riots seems to be reduced as structural factors in French politics have not changed and have, in fact, been reinforced by the events of 2005 . For example, in 2007, President Sarkozy's newest integration laws established a 'Welcome and Integration Contract' for immigrants which obliges migrants to uphold the 'laws and values' of France and take civics and language courses. Furthermore, the November 2007 riots which occurred following the death of two youths in the northern Paris suburb of Villiers-le-Bel (their motorbike was hit by a police car whose occupants subsequently fled the scene) barely raised national debates about integration policies and the structural traits of contemporary French democracy, even though these events received significant attention in the international press. Some even considered this violence to be more significant than that which occurred in 2005, because riot police faced organised gangs who were well-armed with shotguns and petrol bombs (more than 80 police were hospitalised, even though the riots were quite localised geographically). Developments in French integration politics in 2007 make one wonder whether the right questions were asked during the analyses of the 2005 French urban riots. Integration was discussed at length. However, as stated earlier, the quality of French democracy should have been the central focus of these discussions; it forms the focus of the following sections.

\section{The Urban Riots of 2005 Revisited}

More than three years have passed since France's banlieues exploded. In the months following the violence, numerous academic debates were organised to discuss what happened, why it happened and what the significance of it might be. Authors participating in one of these discussions ${ }^{1}$ rightfully identified the geographic (Paul A. Silverstein and Chantal Tetreault), social (Riva Kastoyano) and economic (Ezra Suleiman) exclusion that led to the riots. Most of them also addressed cultural questions regarding identity and the place of migrants in the French state (Jocelyne Cesari). What generally seemed lacking in the analysis of the 2005 violence was context. Work published by the aforementioned scholars in this debate examined the violence itself and its place in French immigration or citizenship politics. However, as the next sub-section demonstrates, broader discussions of French democracy were thinner and there was a lack of comparative analysis with other countries. Thus the riots - and integration politics in France-were placed under a microscope and readily dissected, but rarely were they viewed in a broader context. This comparative view is important given the prominence that French integration policies have obtained in the European Union. Many states, such as the Netherlands and Denmark, have openly moved towards assimilationist policies. Also, in July 2008, President Sarkozy made immigration reform one of his highest priorities for France's 2008 Presidency of the EU. Comparative views on the 2005 riots provide an opportunity to 
better understand what occurred in France, but also to imagine what dangers could await other states interested in adopting French immigration and integration strategies.

\section{The 2005 Riots: A Brief Review of the Literature}

The literature on the urban riots of 2005 was particularly important in France. Even though analyses were conducted fairly quickly in order to reply to these events in a timely manner, one can to draw several central themes from them. One thesis summarised by Gérard Mauger considered these riots to be 'proto-political' movements. 'From the standpoints of their inception and their initial motives, as well as from the standpoints of social identity and the practices of the rioters', these social movements are in line with the repertory of traditional infra-political collective action (Mauger 2007: 148). Like many, Mauger wonders if one can identify in these events the beginnings of a revolt of French suburban youth who have become more conscious of themselves as actors. Unfortunately, he does not provide a convincing response to this question which would support this proposed thesis. Similarly, Bruno Julliard, the leader of the students' union UNEF, which obtained the repeal of the Contrat Première Embauche (CPE) ${ }^{2}$ after several weeks of strikes and fights with the police in Spring 2006, declared to Libération on 1 December 2007 that his main regret was 'not to have succeeded in comparing the problems of suburban youth to those of students'.

The majority of researchers studying the 2005 riots have agreed that they should not be considered as a social movement carrying a political message. For example, Robert Castel underlines the interpretation grid proposed to understand the behaviour of these youths: that is, that they are trapped in a contradiction and that their blind violence is a nihilist response to the dead end in which they find themselves. They are not at all "excluded" ... but they experience their prerogatives through the impossibility of their concrete achievement. They are citizens without the positive attributes of citizenship and they negatively test their membership of the French nation through their non-achievement and unfulfilled promises' (Castel 2006: 783). He adds that 'the attention exclusively placed on crime amongst these youth, making them play the role of the dangerous class, reinforces stigmatisations which they already suffer in different domains of social life. The logic that is put in place in the name of the republican order risks to transform itself into a logic of ghettoisation, as these youths have no other recourse but to close themselves in their own community and change their stigmas by claiming racial pride against the deceptive promises of democracy' (Castel 2006: 808).

Other scholars have defended French citizenship policies. Facing numerous theses that underline the failure of the French integration model, Schnapper (2006) contends that, as far as the acculturation of the descendants of migrants is concerned, more is accomplished in France than in other European countries. She deduces 
therefore that the 'republican model' is not obsolete in principle, but only in its application methods.

Finally, Beaud and Tree Masclet (2006) have identified the 'housing projects (cités) generation' which has been deprived of the tools for political struggle and collective defence, so much so that the most underprivileged faction of the group has often been reduced to acting only through the logic of provocation and, in the end, in order to be heard, to expressing itself through riot and violence. Therefore, studying this generation sociologically offers the means to comparatively understand the objective and subjective difficulties that it encounters in order to construct itself as a collective actor. This is one objective of this special issue, which adds an important international dimension to this debate.

\section{The International Impact of Domestic Riots}

Instead of using the urban violence of 2005 to promote the reform of the French Republican model of government, French leaders and citizens have distanced themselves from the discontent that led to the riots (see Koff, this issue). Unlike 1968, when a national social movement for political rights was embraced by a broader spectrum of citizens who recognised this call for improved access to French citizenship as just, the 2005 urban riots were dismissed as a simple response to discrimination and political provocation. Newly elected President Nicolas Sarkozy openly stated that France's integration strategies 'have failed' and has introduced 'obligatory integration contracts' for migrants that heavily focus on assimilation, including language and culture requirements for long-term (ten-year) resident permits.

As in 1968, participants in the 2005 riots were not challenging the Republic but were seeking access to Republican citizenship (see Duprez in this issue). For this reason, it is not sufficient to discuss the riots within the framework of French immigration politics. These events must be grounded in debates concerning the present state and future of French citizenship and democracy. Moreover, because these events occurred in France - seen by many foreign viewers as a positive model for immigrant integration-discussions of French Republican citizenship and democracy have international ramifications, even though the impact of the riots seems to have only marginally affected debates concerning citizenship and democracy in France. Many states, such as the Netherlands (see Entzinger, this issue), had expressed widespread interest in importing French republicanism; now, the 2005 riots seem to have made European leaders think twice about the utility of this model. Hence, the comparative dimension of this special issue not only sheds light on the riots by introducing an international perspective, but it also addresses the impact of the 2005 violence on European integration agendas. The riots certainly weakened Sarkozy's bargaining position at the July 2007 meeting of the EU Council in which he attempted to convince EU leaders of the utility of implementing European integration contracts based on the French example discussed above (Sarkozy was 
only able to negotiate an agreement that the EU would promote European values such as the respect of equality between men and women). This discussion is almost as important as the riots themselves.

This special issue comprises five articles which analyse different dimensions of the 2005 French urban violence. First, Mucchielli provides first-hand accounts of the October-November riots - collected from interviews with participants and grounded in discussions of French urban policies enacted over the last 25 years - and an explanation of their social geography. Duprez then provides a sociological analysis of the causes of the riots through the historical examination of three institutional factors: 1) the decline of the French welfare state; 2) the impact of centralisation on citizen-polity relationships in poor urban neighbourhoods; and 3) the impact of political bipartisanism on French urban policies.

In addition, this issue includes three comparative pieces. The first, by Harlan Koff, examines the contagiousness of the French riots and explains this phenomenon through a structural analysis of power and ethnicity in France and the United States. The next, by Dietmar Loch, studies social exclusion, power and ethnic identity in Germany and France. Loch specifically focuses on the impact of intermediary political structures as mechanisms that facilitate ethnic mobilisation within the framework of German party politics. He correctly notes that France lacks these structures. Finally, Han Entzinger's contribution examines the impact of the 2005 French riots on contemporary citizenship debates in the Netherlands. He demonstrates how the 2005 violence has had an impact on the Netherlands due to that country's recent adoption of restrictive assimilation policies. These articles all discuss the nature of democracy in immigrant societies and address the international impact of the French riots on various citizenship debates. These broader approaches are significant due to recent victories of right-wing parties throughout Europe and rising tension between ethnic minorities and government authorities in various states. For example, while ethnic rioting is traditionally associated with Great Britain and France, 2007 also marked the first ethnic riots in Italy, as about one hundred Chinese vendors attacked riot police on 13 April, following an incident between one of the vendors and local traffic police in Milan. From just one day of violence, around 25 people were sent to hospital. While the scale of the violence is reduced compared to that which occurred in France, it is significant because this was Italy's first 'immigrant riot'. Moreover, it is important to note that the present government of Silvio Berlusconi, like that of Nicolas Sarkozy, has responded to urban violence with more restrictive immigration and citizenship policies and populist statements which have further increased ethnic tensions. Both these leaders have placed responsibility for integration on migrants and minorities themselves. In France, Sarkozy spearheaded two immigration laws (1 January 2007) which cracked down on clandestine migration, reduced possibilities for amnesty for unauthorised migrants residing on French territory for more than ten years, and made citizenship through marriage more difficult to obtain, in addition to the establishment of the integration contracts mentioned above. Moreover, he called the November 2007 riots 'assassination 
attempts on police', which reinforced his negative relationship with the banlieues. Similarly, Berlusconi's new government has instituted populist policies which have highlighted a national fight against clandestine migration and led to heavy-handed police controls in migrant and Gypsy communities. These policies demonstrate the fact that integration strategies need to be discussed within the framework of power, legitimacy and, above all, leadership. This is the subject of the following section.

\section{Legitimacy and Power in Urban France: Conflicting Leadership}

Throughout the two weeks of rioting, Nicolas Sarkozy was the unquestionable centre of media attention. By calling the rioters 'trash' (racailles), Sarkozy fuelled the escalation of the violence from localised conflict to a national outburst of rage. Journalists covering the riots documented a common anger amongst the participants throughout France and Sarkozy became the political face against which the rioters were reacting. Similarly, Sarkozy's supporters rallied around his tough stance on urban crime and immigration and this position helped him win the French presidency in 2007.

Much has been written about Sarkozy's role in the escalation of the 2005 riots in both the popular and the academic press. Experts such as Olivier Roy and Bernard Salanie $^{3}$ have contended that Sarkozy's actions in 2005 and his present policies indicate a crisis of political leadership in France. They argue that France's political elites remain out of touch with the youth who live in poor neighbourhoods. Of course, this aspect of the political crisis clearly reflects a deficiency in French leadership because of the net separation between leaders and followers (MacGregor Burns 1978).

This vision of French politics correctly recognises the importance of the detachment between French political elites at the national level and residents of the banlieues, where the 2005 uprisings took place. This aspect of the violence indicates a severe problem in the democratic realm of representation which has characterised the French political system in recent years (Knapp 2004). However, the overall crisis of leadership in French integration politics also includes an aspect that is more closely tied to the sphere of governance, defined as the management of conflict in democratic states. The 2005 riots plainly exposed the division of French political elites into different classes. On the one hand, national politicians such as Sarkozy and de Villepin were making strong public pronouncements on immigration, integration and crime that reflected their focus on control and the suppression of the violence. Conversely, local leaders were quietly attempting to calm rioters and create dialogue. Thus, France's national leaders are not only detached from their followers, but they also demonstrate little communication with other leaders in the political system. For example, following the November 2007 riots that began in Villiers-le-Bel, François Pupponi-mayor of neighbouring Sarcelles, one of the suburbs that was struck by violence - clearly stated 'We have heard promise after promise, but nothing has been done in the suburbs since the last [2005] riots, nothing' (Sciolino 2007). Similarly, 
Fadela Amara, a junior minister in the present French government responsible for integration strategies and urban policy has stated, 'Real political will was greatly lacking. There was no follow-up, no assessment. No one really knew who governed urban policy' (McNicoll 2008).

The riots showed that, more than 25 years after France began decentralising its government, local authorities remain a political class in need of a definition. Much of the media's focus was placed on the political divide between the centre-right and the centre-left in their integration strategies. Instead, the true problem in French politics was largely overlooked. The net division between national and local responses to the uprisings is a central element of the leadership crisis in France because it is structural. Local and national officials often follow strategies that conflict, as shown below.

Like most of France's major urban areas (with the notable exception of Marseilles), the Lille métropole was significantly touched by the riots. Local reporters interviewed rioters in the Lille-Sud neighbourhood and typically discussed the tensions with the police, the comments made by Sarkozy and the discrimination that exists in France. While national authorities reinforced the police presence in the neighbourhood and enacted the national curfew instituted by de Villepin, the staff of Mayor Martine Aubry were attempting to quietly mediate with the rioters. Articles in the local newspaper, La Voix du Nord, documented the administration's public meetings with associations and residents in the neighbourhood.

Hence, the problem exposed by the riots was not limited to a lack of understanding on the part of national officials; it also entailed a lack of communication between local and national authorities. How could concertation, the path chosen by local actors, work when national authorities were escalating tensions through policies aimed at control? This was not a case of 'big stick diplomacy', where force was utilised to create dialogue. National authorities showed no interest in communication with associations or residents during the days of the riots. This undermined the actions of local officials throughout the country and de-legitimised their efforts to mediate an end to the uprising. Hence, not only have national authorities lost legitimacy in the French banlieues, they have also damaged the credibility of local officials in these neighbourhoods as well. This has created a serious leadership crisis that is systemic and much more serious than the indelicate words of Nicolas Sarkozy, which have been the main focus of leadership issues related to the 2005 riots.

In fact, since September 2007 Fadela Amara has been holding town-hall meetings throughout France with the objective of creating a 'Marshall Plan' for the country's suburban neighbourhoods (Sarkozy himself did not visit these neighbourhoods during the 2007 election campaign due to his unpopularity in these areas) and improving relationships with local officials. These meetings have been met with great scepticism by many local authorities, who must contend with social marginalisation and security-related issues on a daily basis. Many have lost faith in the promises of national authorities, including those of Sarkozy and Amara. While the aforementioned 'Marshall Plan for the banlieues' aims to create more than 100,000 jobs, better transportation and improved schooling-including the potential for the forced social 
integration of French schools like that which has been typically tied to US integration policies - critics argue that government officials have announced few concrete details concerning the plan's implementation. For example, in response to questions concerning the plan's budget, Minister Amara stated: 'I refuse to have the plan itemised. Why? We can't give a euro figure because each minister will be putting the plans in place, which is new. So we'll actually surpass the billion euros people imagined. When [Sarkozy] as candidate, even as president, said "Marshall Plan for the banlieues", it wasn't in terms of money. It was in terms of mobilization and political will' (McNicoll 2008). Obviously, such answers make local officials nervous because they suggest jargon more than concrete initiatives aimed at improving the quality of democracy in France's banlieues. This has actually led to further debate over the role of local officials in French integration politics. Thus, following the 2007 riots, Didier Vaillant, mayor of Villiers-le-Bel, asked Sarkozy to arrange meetings to address the 'difficulties facing the suburbs'. These difficulties are above all geographic segregation and social inequality, and are the focus of the next section.

\section{Segregation and Social Inequality}

Another major underlying cause of the 2005 and 2007 riots was the lack of employment opportunities in France's banlieues. French cities are marked by a strong dualism of their social systems and increasing socio-spatial disparities. The case of Lille exemplifies this. Previously an industrial region-mines, metal-working, textiles - this metropolitan area witnessed significant deindustrialisation despite the arrival of new industries (notably car manufacturing), and the development of new economic activities, such as large-scale distribution centres and mail-order commerce. These economic shifts affected the social geography of the region because they put an end to a mode of paternalistic management of labour which implicated the residential proximity between entrepreneurs and their workers that lasted until the end of the 1960s and created both social and residential segregation. In fact, owners often met with their executives in rich ghettos surrounding golf courses (the conglomeration of Lille has the third-biggest concentration of large fortunes in France) whereas immigrants - along with traditional working-class families — suffered through the economic crisis and the resulting rise in unemployment in neighbourhoods characterised by public housing or old, degraded workers' homes.

In most of these suburbs or banlieues - above all spaces of poverty-observers often use the security-based term 'sensible' or 'sensitive' in their descriptions. Though these housing projects were often the focus of urban rehabilitation strategies in the 1980s through the implementation of public policies directed at the renovation of these districts, the social and economic problems found in these areas were not resolved at all. These are the places where riots have occurred over the last 25 years.

In contrast, the integrated working classes often share common spaces with middle-class populations in big cities or their residential suburbs. Sociologists have frequently shown in their research that social and residential segregation developed 
from a cultural homogenisation (Dubet and Lapeyronnie 1992). Except for the youth belonging to the most well-to-do urban classes, most working-class young people, including immigrants, attend the same schools as those of the middle classes and have the same dress codes. A small exception must be made for the young people of the poor suburbs of Paris, particularly those living in the Seine-Saint-Denis district, who have dress codes that are often marked by American rap, and jargon known as verlan or 'back-slang', which differentiates them from the rest of the population. Nonetheless, contrary to immigrants in many other countries, most minority youth in France do not speak the language of the country of origin of their parents, in particular Arabic, except for some terms which they integrate into French. Due to the social impact of the differences between these areas, one could make the case that the urban riots of November 2005 should serve as a lesson for politicians to reduce segregation and the phenomenon of exclusion.

In the United States, race riots were often utilised as catalysts for understanding. During a situation similar to that found in contemporary France, democratic administrations in the 1960s attempted to find solutions for the social exclusion that caused widespread urban violence in US cities. For example, Liberson and Silverman (1965) analysed 76 African-American riots that took place between 1913 and 1963. They concluded that the principle causes of these riots were related to the socially inferior position of African Americans in US society, including the importance of social precariousness, marginalisation and exclusion. The authors also contended that social institutions were not capable of responding to the needs of this population. Thus, they argued that the government and the police were mainly responsible for the riots.

In 1967, following a new series of African-American riots, President Lyndon Johnson created the national committee on civic disorder. The main findings of this committee concluded that discrimination in the job market and the accumulation of multiple problems tied to spatial segregation and the maintenance of black ghettosincluding unemployment, drugs and crime-were to blame for the urban eruptions that characterised the US during this period. The commission recommended changing integration strategies aimed at the African-American population and the Johnson administration attempted to enact these ideas. Specifically, these policies called for the police to adopt less aggressive behaviour and change their work habits. This period was also used to introduce more ethnic and racial minorities into police service.

Another country which has witnessed similar outbreaks of urban violence is Great Britain. The first, in the early 1980s, was the famous Brixton riot that was studied first in the Scarman Report and later extensively analysed by the Home Office's working group in 1982. Through the impulse created by these two reports, the English police began encouraging initiatives for ethnic recruitment. This political approach was relaunched following the 'ethnic' riots in Birmingham and Bradford in 1985. Douglas Hogg, the former Secretary of State in the Home Office, organised a conference on police recruitment in order to launch supplementary proposals. A report on the 
impact of these Home Office measures states that, despite the above-mentioned recommendations and programmes, minority recruitment into the police remained low even if it has increased in specific forces (Holdaway 1991; see also Home Office 1990). The urban riots in Great Britain occurred in a context of elevated ethnic exclusion and segregation under which the forms of police participation open to minorities were based on the logic of competitive insertion that was ineffective. Similarly, the racist murder of Stephen Lawrence, who was killed by five or six white youths in Eltham, South-East London, in 1993, marked the starting-point of a major crisis in the British police force, especially the Metropolitan Police. The conclusions of MP Macpherson, who was charged with highlighting eventual police dysfunctions tied to this affair, were oppressive. Macpherson (1998) proposes a definition of a racist incident as '.. any incident which is perceived to be racist by the victim or any other person' and denounced a 'combination of professional incompetence and institutional racism'. He followed this with a series of recommendations to address the situation.

Unlike the cases which occurred in the United States and Great Britain, France has not attempted to find solutions to the problems that caused the 2005 and 2007 riots. Instead, led by Nicolas Sarkozy, French officials have attempted to benefit from the riots by depicting its participants as professional criminals. They have also begun an anti-immigrant campaign in order to attract the conservative electorate away from the camp of radical right-wing politician Jean-Marie Le Pen.

Following the riots, the government enacted measures that seemed to address their underlying causes. Social policies and animation projects aimed at reviving depressed districts and addressing discrimination were to be re-launched and, as stated above, a 'Marshall Plan' for suburban areas was promised by the current government. Without underestimating the achievements accomplished, assessment of these initiatives six months after the 2005 disruptions seemed very thin. Associations complained that subsidies that were promised were never paid. The mayors of suburbs also complained that promised measures were not followed and that the social situations in their areas remained explosive. Moreover, the Minister of Social Services had a lot of difficulty in countering the last-minute revolt conducted by members of the rightwing parliamentary majority who wished to renounce an article of the Solidarité et Renouvellement Urbains (SRU) law. ${ }^{4}$ This article obliges wealthy municipalities refusing to build social housing to pay a tax which is diverted to poorer cities and towns where one finds much social housing and many poor families. The measure, sited within the framework of the law on social cohesion, the Contrat d'insertion dans la vie sociale (Civis), aims to provide support for troubled young people from 16 to 25 years old who do not have a degree and are coming up against obstacles that are blocking their social and professional inclusion. By participating in this programme, a young person commits to making the necessary efforts, with the support of the local mission, to prepare a project of durable employment. Le Monde (29 July 2006) indicated that several hundred young people participating in this programme in the Département $d u$ Nord (of which Lille is the regional capital) saw their allowances cut 
by the state for budgetary reasons. This would seem to indicate that, six months after the riots of November 2005, the government still had not addressed the crisis because of the lack of important electoral stakes. Many of the inhabitants of these districts cannot vote because they are foreigners; many others are not registered to vote, and they abstain.

Nevertheless, analysis of the 2007 presidential elections shows that the urban riots of 2005 had subtle effects on the electoral behaviour in these neighbourhoods. In the case of the Parisian Region - in Yvelines and Hauts-de-Seine, the départements with the highest concentration of wealthy cities in France-the centre-right candidate, Nicolas Sarkozy, with respectively 59 and 56 per cent of the votes, did well compared to the national average of 53 per cent. On the other hand, in the former socialist suburbs where one finds the neighbourhoods that were most significantly touched by the events of October-November 2005, the centre-left candidate, Ségolène Royal, achieved very good results, obtaining 68 per cent in Seine-Saint-Denis and Montreuil, and 55 per cent in Aulnay-sous-Bois, a city where the UMP (the party of President Sarkozy) won local elections. Most observers noted an unusually high interest in the elections in these working-class suburbs, which witnessed higher than usual levels of electoral mobilisation. Clichy-sous-Bois, where the 2005 urban riots began, also noted an increase in electoral participation of more than 30 per cent, again favouring Ségolène Royal. Consequently, Sarkozy's centre-right government has hardened its policies in these marginalised areas, as they provide little electoral support. For example, during the most recent violence in 2007, 1,000 police were deployed to quell four days of rioting in the Parisian suburb of Villiers-le-Bel and the southern city of Toulouse. Sarkozy gave his full support to the police and promised to catch the perpetrators of what he called 'the attempted murder of police'. While these comments are not as inflammatory as those that exacerbated urban tensions in 2005, they still demonstrate his government's lack of attention to the poor relationship between the French police and the inhabitants of marginalised areas. This was one of the most important causes of the 2005 violence and, as the events of November 2007 demonstrate, the tension persists today, as we shall see below.

\section{The Withdrawal of Crime Prevention and Neighbourhood Police Policies}

One of the main problems in France's poor neighbourhoods highlighted by the 2005 and 2007 riots is the poor relationship between many of the local residents and the national police. The French model of crime prevention since the 1980s can be placed in the 'social prevention' category, where programmes focus on the potential perpetrators of antisocial acts. With the objective of intervening on the causes of delinquency rather than on its effects, which are the focus of the situational AngloAmerican models of crime prevention, French policies during this period have emphasised social action through work with youths living in so-called 'sensitive' neighbourhoods. At the end of the 1990s, the government of ex-Prime Minister Lionel Jospin had expanded these strategies by creating assisted employment for 
youth (emplois jeunes) and by attempting to install a neighbourhood police force that works more closely with inhabitants of marginalised districts and integrated preventative measures.

In effect, youth unemployment was particularly high in France and closely tied to education levels (generally higher education levels correlated with lower unemployment rates), but it had a particular characteristic which is underlined by Dominique Duprez in his contribution to this special issue: since the 1990s, young graduates in marginalised neighbourhoods have not followed this general trend. Stigmatised for living in poor areas, there has been an accumulation of difficulties which have prevented many of these young graduates from entering the labour force. Some of the Jospin government's proposed jobs, such as those with associations, municipal services (libraries, mediation), the police, etc. were precarious (for a maximum of five years) and poorly paid, but these positions permitted young people to save face and helped them integrate economically. The questioning of the worth of these policies by President Jacques Chirac and his conservative governments has created a lot of resentment in the banlieues and indirectly increased the value of the illegal economy, especially in terms of activities related to the drug trade (Duprez and Kokoreff 2000).

Sarkozy has also openly questioned the worth of creating a community police force in France - the police in France are part of the state and their recruitment is national. The main rule is that policemen do not work in their home regions until the end of their careers and they are the armed wing of the central government's power. Mayors have no authority over the police operating within their territory. Research on police in France has underlined the existence of tensions between them and youths in deprived neighbourhoods. In particular, scholars have noted the prevalence of arbitrary identity checks, especially amongst young ethnic minorities (see Mucchielli, this issue; also Jobard and Névanen 2007). Not even the neighbourhood police were able to improve relations between young people in the banlieues and national police, despite the presence of local youths recruited through social employment programmes. Neighbourhood officers generally patrolled districts on foot, in pairs or threes, and small police stations were opened to welcome residents. The disappearance of this experiment signifies a restoration of a purely repressive police force, the cutting of links with local communities, and a return to a climate of confrontation, strongly encouraged by Sarkozy. The flight from the police of three young people who had done nothing wrong - the origin of the 2005 uprisings because it resulted in two dramatic deaths by electrocution - is symptomatic of the climate which has since reigned in France. International comparisons are interesting here because, in identical conditions, Great Britain has tried to actively address reports of racist attitudes within the police force. This has not been the case in France.

Admittedly, a left-wing government at the end of 1990s, in which Jean Paul Chevènement was Minister of the Interior, had tried to introduce young people from poor neighbourhoods into the national police on the basis of a report that migrant youths were under-represented, despite the fact that most of this population had attained French citizenship. Nonetheless, studies have demonstrated the limited reach 
of this policy which was quickly abandoned by the political right when it returned to government (Duprez and Pinet 2001).

This question of the relationship between the police and the inhabitants of immigrant districts will be evoked in several articles in this special issue. Indeed, in most of the countries examined, urban riots have started over conflicts between police and young people. In the French case, it is the combination of the crises of social policies and employment assistance for young people on the one hand, and the presence of daily (even if only symbolic) police violence on the other, which explains the spread of the 2005 riots to about 300 municipalities during three weeks of uprisings. Little has changed since the 2005 violence or even since the 2007 riots. During Sarkozy's first six months in office as president, he has focused significantly on urban crime rather than on tensions between local youths and the police. His most important initiative for dealing with youth crime has been punitive in nature. In July 2007, the government passed a law that required tougher minimum sentences for repeat offenders and, in many cases, permitted youths between the ages of 16 and 18 to be tried and sentenced as adults. Thus, suburban communities and national authorities are drifting further apart. Policies such as these laws on youth crime highlight more than just integration difficulties in France. They speak of serious citizenship problems in France's marginalised neighbourhoods. In fact, most of the riots' participants were not challenging French notions of citizenship but were denouncing their lack of implementation in their neighbourhoods.

\section{The 2005 Riots: More Republican than Anti-Republic}

International observers of French politics have long discussed their conflictive nature. Some have focused on a 'culture of conflict' (Tilly 1986) while others have examined structural variables, such as the centralised nature of the French state and the nature of political power in the political system (Hall 1986). French tendencies for rebellion have been documented in numerous arenas, such as interest representation (social movements), political economy (strikes), and even electoral behaviour (protest votes). Why, then, should the political behaviour of immigrants and minorities be identified as deviating from this tradition? Following the 2005 riots, France was hit by violent student strikes in 2006 and massive transport strikes in 2007.

The 2005 riots-like those that preceded them on a smaller scale and the November 2007 riots - have always been treated as challenges to the French republican model of democracy (Bouamama 1994), which elevates the importance of the collective good and the individual citizen and ignores communitarian affiliation. It has often been assumed that minorities participating in the riots were challenging this system merely because they were ethnic minorities. For example, Canadian immigration specialists such as Jeffrey Reitz and Randall Hansen blamed the riots on the exclusion of France's second-generation migrants. They claimed that such rioting is less likely in Canada due to that country's selective immigration system. Claude Laverdure, Canada's ambassador to France, similarly stated in a CBC 
article on the 2007 French urban riots, 'We seek immigrants. We go after people around the world and welcome them.... France does not have such a policy. They simply inherit immigrants. 5 Such positions of course, shift responsibility for integration from the state to the migrants themselves. Moreover, these positions reflect the logic of the Sarkozy government's immigration policies based on targeted or 'controlled immigration' (immigration choisie) rather than on 'uncontrolled immigration' (immigration subie).

Many works have focused on the rise of similar migration control policies both in Europe and in other advanced industrial states. Many scholars such as Hargreaves (2007) have also written about the socio-economic exclusion and geographic segregation that led to the 2005 urban riots in France and the 2007 aftershocks. The link, however, needs to be made between these fields, due to the prominence of French immigration and integration strategies in European politics. The French presidency of the EU began in July 2008 and Sarkozy quickly put immigration reform as one of the highest priorities on his European agenda. Sarkozy has unveiled a new immigration and asylum pact which includes the sharing of information on legal immigrants, the simplifying of procedures for deporting undocumented migrants, tighter border controls and extra assistance for migration control in the EU's Eastern and Mediterranean border states. He also planned to institute EU-wide integration contracts based on the French model, but this proposal was rejected by the Socialist government of Spain.

The French riots certainly indicate the weakness of French migration policies and the dangers that such strategies represent for the EU, should they be adopted at the European level. While the media (and certain politicians) often framed the riots as 'a threat to the French Republic', this position could hardly be further from the truth. At no time did the rioters stake any claims to ethnic or religious rights. Moreover, the ethnic composition of those participating in the riots varied greatly. Whereas past riots were often portrayed as the work of youths of North African descent, the 2005 uprisings (and the 2007 riots) were clearly multi-ethnic in demographic terms. In fact, much of the popular media focused on the increased visibility of youths of subSaharan-African descent compared to the past.

Various European states are now dealing with so-called ethnic, cultural or religious tensions. In Great Britain, political protests against the police have occurred in Muslim neighbourhoods where the authorities have concentrated anti-terrorism efforts and where local inhabitants claim that they are victims of discrimination. Italy is now dealing with its first episodes of ethnic violence as well as police crackdowns on migrants and Gypsies. In Denmark and the Netherlands, religious tensions have escalated due to various high-profile episodes. However, the question of ethnic tension/violence in Europe does not seem to be simply cultural, nor is it only related to problems of social integration. These issues are above all questions of citizenship, rights and equality. As the EU, under Sarkozy's leadership, aims to install a system of controlled or 'chosen migration' based on circular flows and temporary stays, many critics fear that this will lead to the re-intallation of a guestworker system and 
exacerbate socio-economic exclusion. These positions are not centrally focused on cultural issues. They deal with labour-market economics and political questions directly related to the quality of democracy in Europe which are tangible. The 2005 riots in France highlighted this point.

These riots followed the French tradition of protest in the face of political and socio-economic exclusion. A brief dissection of the uprisings demonstrates that there were no cultural elements to be found during the two weeks of violence. They began, like many others before them, as a response to perceived injustices committed by the police, who are often viewed as intruders in poor urban neighbourhoods rather than as public servants. Their escalation occurred because a politician, hoping to contribute to the political capital necessary for a presidential campaign in 2007, made indelicate statements concerning the residents of poor urban neighbourhoods. Offended youths rallied against this message and displayed their anger at their lack of representation in the French political system by attacking cars, buses and public buildings. Most of the vandalism targets that were hit during the riots (except for cars) were symbols of the French state (i.e. schools, post offices, public buses, etc.). Finally, the rioters' statements to the press during this period focused on socioeconomic exclusion and social discrimination, both of which are antitheses to the values on which the French Republic has been founded.

Thus, the rioters were not challenging the French Republic, but they were contesting the behaviour of political leaders who were acting in an 'unrepublican' manner themselves, as well as the failure of a socio-political system that refused the rioters access to Republican citizenship. The 2005 riots were not significant simply because they highlighted the failure of integration politics in France. They were important because they clearly demonstrated the contemporary weakness of democracy in France. In the past, French political systems had improved access to citizenship for peasants, factory workers, women, students, etc. following periods of social upheaval. The same alterations need to be made today for immigrants and ethnic minorities. Otherwise France - and possibly Europe, should the EU follow the French example-will continue to witness further Republican challenges from migrants to an increasingly unrepublican political system. This has already occurred in 2007.

\section{Notes}

[1] These authors, and others, participated in a debate organised by the Social Science Research Council on the following website: http://riotsfrance.ssrc.org/.

[2] This proposed employment contract would have allowed employers to dismiss employees within two years of recruitment, without any compensation and without any obligation to justify the dismissal.

[3] Social Science Research Council (2006) debate, online at http://riotsfrance.ssrc.org/.

[4] LOI $\mathrm{N}^{\circ}$ 2000-1208 DU 13 DÉCEMBRE 2000 RELATIVE À LA SOLIDARITÉ ET AU RENOUVELLEMENT URBAINS. [LAW N $\mathrm{N}^{\mathrm{O}} 2000-1208$ of 13 December 2000 on urban solidarity and renewal]. According to INSEE, France had 3.5 million people living in sub- 
standard housing in 2002. In council housing the situation was no better: 22 per cent of the inhabitants were unemployed, and many more than half had incomes below the 60 per cent ceiling. In a bid to reverse this trend, the SRU law, adopted in 2000 by the Jospin government, set a 20 -year goal: 20 per cent of social housing for communes of more than 1,500 inhabitants in the Parisian region, and 3,500 in the provinces. Failure on the part of communes to provide this housing would result in penalties being imposed, though these were only small to start with. Thus the rich commune of St Maur-des-Fossés (Val-de-Marne) only pays 800,000 euros per year in penalties, in spite of only making a minimal effort to conform to the law concerning social housing (5.5 per cent only of its housing stock in January 2005 was devoted to it compared to 5.4 per cent three years earlier). [Translation $J E M S]$.

[5] CBC News (2007) 'France Riots: Understanding the Violence'. http://www.cbc.ca/news/ background/paris_riots/, 28 November.

\section{References}

Beaud, S. and Masclet, O. (2006) 'Des "marcheurs" de 1983 aux "émeutiers" de 2005: deux générations sociales d'enfants d'immigrés', Annales, 61(4): 809-43.

Bouamama, S. (1994) Dix ans de marches des Beurs. Chronique d'un mouvement avorté. Paris: Desclée de Brouwer.

Castel, R. (2006) 'La discrimination négative: le déficit de citoyenneté des jeunes de banlieue', Annales, 61(4): 777-808.

Cesari, J. (2005) 'Ethnicity, Islam and les banlieues: confusing the issues', in SSRC (eds) Riots in France. Online at http://riotsfrance.ssrc.org/cesari/, viewed 28 June 2006.

Dubet, F. and Lapeyronnie, D. (1992) Les quartiers d'exil. Paris: Le Seuil.

Duprez, D. and Kokoreff, M. (2000) Les mondes de la drogue. Paris: O. Jacob.

Duprez, D. and Pinet, M. (2001) 'La tradition, un frein à l'intégration: le cas de la police française', Les cahiers de la sécurité intérieure, 45: 111-38.

Hall, P. (1986) Governing the Economy: The Politics of State Intervention in Britain and France. New York: Oxford University Press.

Hargreaves, A. (2007) Multi-Ethnic France: Immigration, Politics, Culture and Society. London: Routledge ( $2^{\text {nd }}$ edition).

Holdaway, S. (1991) 'Race relations and police recruitment', British Journal of Criminology, 31(4): 365-82.

Home Office (1990) Ethnic Minority Recruitment into the Police Service. London: Home Office, Circular 33.

Jobard, F. and Névanen, S. (2007) 'La couleur du jugement: discrimination dans les décisions judiciaires en matière d'infractions à agents de la force publique (1965-2005)', Revue Française de Sociologie, 48(2): 243-72.

Kastoryano, R. (2006) 'Territories of identities in France', in SSRC (eds) Riots in France. Online at http://riotsfrance.ssrc.org/kastoryano/, viewed 28 June 2006.

Knapp, A. (2004) Parties and the Party System in France: A Disconnected Democracy? New York: Palgrave Macmillan.

Liberson, S. and Silverman, A.R. (1965) 'The precipitants and underlying conditions of race riots', American Sociological Review, 30(1): 87-98.

MacGregor Burns, J. (1978) Leadership. New York: Harper \& Row.

Macpherson, W. (1998) Inquiry into the Matters Arising from the Death of Stephen Lawrence on 22 April 1993 to Date, in Order Particularly to Identify the Lessons to be Learned for the Investigation and Prosecution of Racialy Motivated Crimes. London: Home Office.

Macridis, R. (1975) French Politics in Transition. Cambridge: Winthrop. 
Mauger, G. (2007) 'La commémoration médiatique de l'émeute de novembre 2005', in Pinto, E. (ed.) Pour une analyse critique des médias. Le débat public en danger. Broissieux: Editions du Croquant, 129-50.

McNicoll, T. (2008) 'Fadela Amara: Madame Marshall Plan’ Newsweek, http://www.newsweek.com/ id/117816, 1 March.

Schnapper, D. (2006) 'L'échec du “modèle républicain"? Réflexion d'une sociologue', Annales, 61(4): 759-77.

Sciolino, S. (2007) 'Paris Suburb Riots Called "A Lot Worse" than in 2005', International Herald Tribune, http://www.iht.com/articles/2007/11/27/europe/riots.php?page =2, 27 November.

Silverstein, P. and Tetreault, C. (2006) 'Postcolonial urban apartheid', in SSRC (eds) Riots in France. Online at http://riotsfrance.ssrc.org/silverstein_tetreault/, viewed 28 June 2006.

Suleiman, E. (2006) 'France: one and divisible', in SSRC (eds) Riots in France. Online at http:// riotsfrance.ssrc.org/suleiman/, viewed 28 June 2006.

Tilly, C. (1986) The Contentious French. Cambridge: Harvard University Press. 
Copyright of Journal of Ethnic \& Migration Studies is the property of Routledge and its content may not be copied or emailed to multiple sites or posted to a listserv without the copyright holder's express written permission. However, users may print, download, or email articles for individual use. 
Copyright of Journal of Ethnic \& Migration Studies is the property of Routledge and its content may not be copied or emailed to multiple sites or posted to a listserv without the copyright holder's express written permission. However, users may print, download, or email articles for individual use. 